\title{
Comments
}

\section{INFORMER'S WORD AS THE BASIS FOR PROBABLE CAUSE IN THE FEDERAL COURTS}

The informer is a valuable part of the law enforcement effort, particularly in those areas of crime where the premium is on secrecy and the outsider finds it difficult or impossible to obtain information and evidence. ${ }^{1}$ Because informers have proven useful in law enforcement, the courts have developed the "informer's privilege" as a device for encouraging informers to communicate information without fear of subsequent retribution. This Comment will be limited to federal law and will focus upon the problems generated by the invocation of the privilege in cases where an informer's information is used to establish probable cause for arrest or search. ${ }^{3}$ First, the substantive standards limiting rehance upon hearsay in the probable cause context will be set forth. Second, examination will be made of the judicial compromise whereby the desirability of a detailed factual showing in satisfaction of these standards is balanced against the competing pohicy of protecting the informer. Finally, the advantages and disadvantages of disclosure as a protective device in probable cause cases will be assessed, and a rule for disclosure suggested.

All federal searches inust be based upon probable cause. ${ }^{4}$ Where

${ }^{1}$ See Vollmar, The Police IN Modern Socnety 87 (1936); Donnelly, Judicial Control of Informants, Spies, Stool Pigeons, and Agent Provocateurs, 60 YAIE L.J. 1091 (1951); Comment, An Informer's Tale: Its Use in Judicial and Administrative Proceedings, 63 YALE L.J. 206 (1953).

2 See generally Roviaro v. United States, 353 U.S. 53 (1957); 8 WIGMORE, EvmENCE 8 2374 (McNaughton rev. 1961); Annot., 76 A.L.R.2d 257 (1961). The government's privilege is primarily directẹd toward preventing disclosure of the name of its informer, but in those cases where disclosure of the informer's information would tend to disclose the informer's identity, then the information itself may be privileged to the extent necessary to protect the informer. Roviaro v. Unted States, supra at 60 . The method, manner, and circumstances of the government's acquisition of the information may also be privileged. Cf. Bowman Dairy Co. v. Umited States, 341 U.S. 214, 221 (1951). The privilege is lost where the informer's identity has been discovered by the accused or others who would have cause to resent his actions. Roviaro v. United States, supra at 60 .

3 The probable cause cases are to be distinguished from those in which the informer was an eyewitness to or a participant in the crime, or otherwise involved to the extent that his testimony might be relevant to the issue of the accused's guilt or innocence. For those cases, the Supreme Court in Roviaro v. United States, 353 U.S. 53 (1957), set down a rule requiring disclosure where "relevant and helpful to the defense of an accused," or where "essential to a fair determination of a cause." Id. at 60-61.

4 Federal searches must be made under authority of a warrant, except where the surrounding circumstances make procuring a warrant impracticable, Carroll v. United States, 267 U.S. 132 (1925), or the search is made incident to a valid arrest, United States v. Rabiowowitz, 339 U.S. 56 (1950) (arrest pursuant to arrest warrant); Draper v. Urited States, 358 U.S. 307 (1959) (arrest without warrant). A search warrant may only issue 
such a basis of probable cause is lacking, evidence seized during a search is open to a motion to suppress. ${ }^{5}$ When the relevant facts upon which his judgment is based are entirely within the knowledge of the searching officer, the judge, or, if a warrant is first sought, ${ }^{6}$ the United States commissioner, must determine whether those facts are legally sufficient to support the officer's conclusion as to probable cause. When, however, an informer's oral communications to the officer are introduced as part or all of the basis for arrest or search, additional problems arise for the judicial officer. What is the source of the informer's information? He may be reporting what he himself has only heard rather than personally observed, giving voice to a mere rumor. His report may consist of what he definitely does know to be fact, mixed with embellishments for which he cannot personally vouch-products of his suspicions or guesswork. He may, for perverse motives of his own, be telling a conplete lie. ${ }^{7}$ Where the informer himself does not appear before the commissioner or judge, there is no direct or cross-examination of the original source of the information and therefore no direct check on these possibilities.

The federal courts have nevertheless held that hearsay may support both the issuance of a search warrant ${ }^{8}$ and an arrest without a warrant. ${ }^{9}$ The two leading cases have cited as support for their acceptance of hearsay the view expressed in Brinegar v. United States" that, "In dealing with probable cause, ... as the very name implies, we deal with probabilities. These are not technical; they are the factual and practical considerations of everyday life on which reasonable and prudent men, not legal technicians, act."11 Given this hiberal approach, the federal

upon a showing of probable cause. U.S. ConsT. amend. IV; FED. R. CRIM. P. 41 (c). In order to secure uniform safeguards against unlawful search and seizure, both searches without warrant and arrests with or without warrant have been made subject to that same probable cause standard. See Carroll v. United States, supra (searches); Wong Sun v. United States, 371 U.S. 471, 479 (1963); Draper v. United States, supra (arrests).

One of the most conmonly cited definitions of probable cause is set forth in Brinegar v. United States, 338 U.S. 160, 175-76 (1949): "Probable cause exists where 'the facts and circumstances within ... [ [the officers'] knowledge and of which they had reasonably trustworthy information [are] sufficient in theniselves to warrant a man of reasonable caution in the .belief that' an offense has been or is being committed."

5 FED. R. CRIM. P. 41 (e).

6 Warrants are issued under Federal Rules of Criminal Procedure 3, 4 (arrest warrant) and Federal Rule of Criminal Procedure 41 (c) (search warrant).

7 On the possible motives for prevarication, see generally Jones v. United States, 266 F.2d 924, 928 (D.C. Cir.) (granting leave to appeal in forma pauperis, statement by Bazelon, J.), appeal on merits, 271 F.2d 494 (D.C. Cir. 1959), cert. denied, 362 U.S. 944 (1960); Harney \& Cross, The Informier IN LAW Emforcement 33-39 (1960).

8 Jones v. United States, 362 U.S. 257 (1960).

- Draper v. United States, 358 U.S. 307 (1959).

10338 U.S. 160 (1949).

11338 U.S. at 175. Brinegar disapproved earlier dictum in Grau v. United States, 287 
courts have been faced with the problem of minimizing or eliminating the dangers inherent in the use of secondhand information.

I

\section{SAFEGUARDS LIMITING RELIANCE ON HEARSAY}

\section{A. Verification and Corroboration}

An obvious safeguard against a lying or inaccurate informer is judicial insistence upon independent police investigation aimed at supplementing and corroborating the information received. Where information from an informer has stimulated a police investigation which has subsequently developed beyond inere corroboration to a showing of probable cause entirely apart from the mformer's communication, it is held that inquiry into the information's contents, source, and basis is unwarranted and the informer's privilege remains absolute. ${ }^{12}$ More often, police investigation will not develop such an independent showing, yet will be productive of personal observations and other facts strong enough, taken collectively, to sustain a reasonable belief that the informer's information is accurate. ${ }^{13}$ In such cases, the information, as distinguisled from its source, has been held reliable ${ }^{14}$ and probable cause thereby established. That the informer has been of unknown rehability, ${ }^{15}$ or even shown to be a pathological liar ${ }^{16}$ has not altered the result; as long as his information has been "corroborated in essential particulars or verified in essential parts," inquiry into the informer's reliability or the basis for his information has been deemed superfluous. ${ }^{17}$ The apparent rationale of these holdings is that no larm results from taking the information at face value, because the probability of a lying or inaccurate informer has been sufficiently reduced by corroborative facts and observations.

U.S. 124, 128 (1932), that the criteria for the admissibility of evidence on the issue of guilt or innocence were also applicable to the determination of probable cause, citing a large difference in the "quanta and modes of proof" required for each. 338 U.S. at 173.

12 E.g., Scher v. United States, 305 U. S. 251 (1938) ; United States v. Santiago, 327 F.2d 573 (2d Cir. 1964); Lane v. United States, 321 F.2d 573 (5th Cir. 1963), cert. denied, 377 U.S. 936 (1964).

13 Typical elements in such a showing are prior arrests or convictions for the same offense, suspicious or evasive conduct, association with known violators, receipt of the same information from other informers, and flight or other guilty conduct upon knowledge of an officer's presence.

14 E.g., United States v. Woodson, 303 F.2d 49 (6th Cir. 1962); United States v. Williams, 219 F. Supp. 666 (S.D.N.Y. 1963), afj'd per curiam, 336 F.2d 183 (2d Cir.), cert. denied, 379 U.S. 857 (1964).

15 See, e.g., United States v. Woodson, supra note 14.

16 See, e.g., United States v. Irby, 304 F.2d 280 (4th Cir.), cert. denied, 371 U.S. 830 (1962). In addition, the informer had a history of mental illness and a narcotics record. The court commented: "It is of hitle moment that ... [the informer] was shown to be a man of unstable character and credibility. ... [T] [Te information was tested and found to be correct in important details before the arrest was made." Id. at 283.

17 Katz v. Peyton, 334 F.2d 77 (4th Cir.), cert. denied, 379 U.S. 915 (1964). 


\section{B. Inquiry into the Informer's Reliability and Basis}

Personal verification or corroboration of the facts of an informer's communication is not always practicable from a police standpoint, particularly if direct observation is difficult or immediate action is required. Consequently, where corroborative facts known to the officer have been few and insufficient, the focus of judicial scrutiny has shifted to the informer in an effort to find, by examination of his reliability and the source of his information, some additional basis for accepting or rejecting the prosecution's contention that there was probable cause for an arrest or search.

Aguilar v. Texas, ${ }^{18}$ decided in 1964 , clearly sets forth the Supreme Court rule where sufficient corroboration is absent: the "underlying circumstances" of both the informer's conclusion of guilt and the officer's conclusion that the informer is reliable must be put forth before the reviewing magistrate..$^{19}$ Aguilar held invalid a searcl warrant issued by a local magistrate on the strength of an affidavit which averred only that the affiants had received "reliable information" from a "credible" person concerning narcotics activities of the defendant. The affidavit was devoid of any other particulars. The Court made no mention of any necessity for corroboration independent of the information itself, and presumably, if the "underlying circumstances" of both the informer's belief and the officer's belief in his reliability had been sufficiently set out, probable cause would have been established.

Aguilar is essentially a synthesis of two prior Supreme Court cases, Draper v. United States ${ }^{20}$ and Jones v. United States. ${ }^{21}$ Draper established that information from a reliable informer, supplemented only by corroborative facts totally innocent in themselves, could support an arrest and incident search without a warrant. ${ }^{22}$ The informer's reliability

18378 U.S. 108 (1964).

$10 \mathrm{Id}$. at 114 .

20358 U.S. 307 (1959).

21362 U.S. 257 (1960).

22 In addition to his information that the defendant was peddling narcotics, the informer supplied particulars as to the defendant's presence at the Denver railroad station, his description, dress, "fast walk," and the tan zipper bag in which the narcotics allegedly would be carried.

Given a reliable informer, as in Draper, verification of such innocent details, although not directly suggestive of guilt, probably does perform a legitimate function. It reduces the possibility that the reliable informer's information in a particular instance, although given in good faith, is inaccurate. Where there is no pre-established reputation for reliability, the value of innocent corroboration, without more, is questionable.

Innocent corroboration suggests that a part of the informer's story is true, but only that part which is entirely consistent with perfectly legal everyday activity. See Jones v. United States, 326 F.2d 124, 130 (9th Cir. 1963) (concurring opinion), cert. denied, 377 U.S. 956 (1964) (dissenting opinion). Drop the assumption of a reliable informer, or even posit one who has a history of unreliability, and a strong showing of guilty corroboration 
in Draper had been established by testimony of federal narcotics agents that the informer liad been a "special employee" of the Denver office of the Bureau of Narcotics for six montlis and had given reports "from time to time" which had been found to be "accurate and reliable" and for which he had received small sums of money. Jones examined the problein of the factual basis for the informer's allegations, a problem which Draper had not considered. Admitting that the affiant's suspicion that probable cause exists is inadequate support for a warrant, ${ }^{23}$ Justice Frankfurter reasoned that a warrant could not issue on the mere suspicion of a third person. A warrant could issue, however, when based on the personal observations of a third person, "so long as a substantial basis for crediting the liearsay is presented."24 The affidavit had set out the informer's basis for his allegations, relating lis claim that he had purchased narcotics from the defendant's apartment on "many occasions," his last purcliase having been made the day previous to the detective's application for the warrant. The Aguilar synthesis combined the requirement that the informer be reliable with the requirement that he have an adequate basis for his allegations, emphasizing the need for "underlying circumstances" in support of each element.

may still be regarded as a sufficient safeguard against lies or inaccuracies. See United States vi Irby, 304 F.2d 280 (4th Cir.), cert. denied, 371 U.S. 830 (1962). Innocent corroboration is so completely ambiguous that, even if extensive, it seems incapable of providing a similar safeguard. With ease, an inventive informer could incorporate certain innocent factual details, such as those found in Draper, into a larger tale of criminal activity based on lies or inspired guesswork.

Reliance on innocent corroboration alone thus places a premium on a history of personal reliability that may not be present where guilty corroboration is found. See Jones v. United States, 266 F.2d 924, 929 (D.C. Cir.) (granting leave to apperal in forma pauperis, statement by Bazelon, J.), appeal on merits, 271 F.2d 494 (D.C. Cir. 1959), cert. denied, 362 U.S. 944 (1960). Dicta in a few cases that verification of such innocent details alone establishes an informer's personal reliability seem clearly wrong. E.g., Jones v. United States, 326 F.2d 124 (9th Cir. 1963), cert. denied, 377 U.S. 956 (1964); Costello v. United States, 324 F.2d 260 (9th Cir. 1963), cert. denied, 376 U.S. 930 (1964), affirming after vacation and remand in 298 F.2d 99 (9th Cir. 1962).

${ }^{23}$ See Nathanson v. United States, 290 U.S. 41 (1933); see generally the dissenting opinion of Douglas, J., in Draper v. United States, 358 U.S. 307, 314 (1959).

24362 U.S. at 269 . Justice Frankfurter found that substantial basis in the prior instance of accurate information from the informer, the defendant's known addiction, and the receipt of the same information fron sources not claimed to be reliable. Aguilar apparently makes such independently corroborative elements an unnecessary part of a "substantial basis," provided the "underlying circumstances" of the informer's basis and the officer's belief in his reliability are sufficiently set out. There has been some doubt, prior to Aguilar, that Jones could be so construed. See, e.g., Ramirez v. United States, 279 F.2d 712, 715 (2d Cir), cert. denied, 364 U.S. 850 (1960): "[U]nder Jones, the affiant must not only believe the hearsay report, but, in all likelihood, the affiant must further demonstrate that his informant las established a reputation for reliability so as to be worthy of belief. In addition, Jones may require that the affidavit include some factual information independently corroborative of the hearsay report." 
II

\section{REQUIRED SHOWING UNDER THE Aguilar RULE}

The Aguilar rule is easily stated. The problems arise in determining the precise extent of the showing that should be demanded by the reviewing magistrate. The inore detailed the factual elaboration supporting the informer's accusation and the officer's assertion of his reliability, the greater the threat to the informer's privilege, since clues are thereby provided to the informer's identity.

\section{A. Basis of the Information}

The showing required in support of the informer's accusation will no doubt be subject to the same probable cause standards used in appraising an officer's own observations. ${ }^{25}$ The underlying circumstances of the informer's belief have thus far consisted in the informer having himself made a narcotics purchase from the defendant ${ }^{26}$ or having seen the contraband firsthand ${ }^{27}$-relatively. simple cases. How the courts will handle more complex bases for the informer's allegations remains to be seen. In theory, certainly, the informer is justified in basing his judgment on the same type of delicately interlocking fact situations that are deemed sufficient when an officer is making the determination of probable cause. The only practical bar to the more pointed and extensive questioning of the informer that would be required might be the informer's own unwillingness to specify the source of his information.

For some reason, defense counsel have been slow to request government elaboration of the informer's basis in the non-warrant cases, where the initial judicial assessinent of probable cause is made on the pretrial motion to suppress, after the search has been consummated. Part of the reason may be the Draper decision's failure to consider the issue. No basis was indicated in Draper for the informer's information, a fact noted by Justice Douglas in his dissent. ${ }^{28}$ No doubt such a request would have to be lonored, however, since the requirements for probable cause for the issuance of a warrant constitute minimal standards for cases where no warrant has been secured in advance. ${ }^{29}$ However, failure to con-

25 See note 23 supra and accompanying text.

26 E.g., Jones v. United States, 362 U.S. 257 (1960) (purchases on "many occasions," the last purchase on day prior to issuance of warrant); Walker v. United States, 327 F.2d 597 (D.C. Cir. 1963), cert. denied, 377 U.S. 956 (1964) (purchases during preceding month, last one on morning of warrant issuance).

27 E.g., Rugendorf v. Umited States, 376 U.S. 528 (1964) (informer saw stolen furs in defendant's basement); Brandon v. United States, 270 F.2d 311 (D.C. Cir. 1959), cert. denied, 362 U.S. 943 (1960) (informer had been to apartment and confirmed arrival of narcotics shipment).

28358 U.S. at 315.

20 See, e.g., Wong Sun v. United States, 371 U.S. 471, 479-80 (1963); Jones v. Umited. 
sider the informer's basis in the absence of challenge is probably unexceptionable for the reason that a specific showing as to basis, like one on reliabihty, runs the risk of inadvertent disclosure of the informer's identity. ${ }^{30}$ Because the intial judicial determination of probable cause is being made in an adversary proceeding, the defendant may legitimately be left the responsibility of demanding further particulars in support of any of the government averments. ${ }^{31}$

\section{B. Reliability of the Informer}

What constitutes an adequate government showing establishing reliability is much more in doubt. Aguilar focused on the need for factual support for the informer's allegations. There was no elaboration of the statement that the "underlying circumstances" requirement also applied to the officer's belief in reliability. Certainly the purely conclusionary averments of reliability accepted in a few earher cases $^{32}$ are now inadequate. But what of the highly generalized recitals, unaided by supporting particulars, which have frequently appeared in the past? "Previously rehable informer," "informer of proven reliability," "informer who has given accurate information in the past"--these vague phrases hint at a consistent history of reliability, but are really highly ambiguous. The instances of inaccurate information may have outnumbered instances where the information proved correct. ${ }^{33}$ The information may have led directly to an arrest and conviction or may only have served as a vague lead which later was verified in some particulars but not in others.

Aguilar apparently accepts such recitals as satisfactory. The Court

States, 362 U.S. 257, 270 (1960). But see Hawkins v. United States, 288 F.2d 537 (8th Cir.), cert. denied, 366. U.S. 975 (1961), holding that once reliability is established, the source of the informer's information is an unnecessary consideration. The informer's information was avowedly based on what he had overheard in a nightclub. The court relied on Draper's failure to question the informer's source, and did not mention Jones. Aguilar v. Texas, 378 U.S. 108 (1964), has phrased the Jones requirement more explicitly, with the result that one recent non-warrant case has treated examination of the informer's basis as proper procedure, if the defendant requests it. See Perry v. United States, 336 F.2d 748 (D.C. Cir. 1964).

30 Since the government need not volunteer disclosure, United States v. Conforti, 200 F.2d 365 (7th Cir. 1952), cert. denied, 345 U.S. 925 (1953), neither should it be required to volunteer, given the scope of the informer's privilege, see note 2 supra, any information that would tend to identify its informer.

31 In contrast, the officer's appearance before the commissioner is ex parte, and the commissioner is bound to ascertain the existence of all the facts necessary to a determination of probable cause. Since a warrant may issue only on affidavit, FED. R. CRIM. P. 4I(c), those facts must be fully set out in the affidavit in order to sustain the commissioner's finding of probable cause. United States v. Sims, 201 F. Supp. 405 (M.D. Tenn. 1962).

32 E.g., United States v. Eisner, 297 F.2d 595 (6th Cir.), cert. denied, 369 U.S. 859 (1962), where the court rested its finding of probable cause entirely on information received by an FBI agent which, the affidavit averred, he "... [believed] to be reliable."

33 See Urited States v. Peisner, 311 F.2d 94 (4th Cir. 1962), where a "reliable informant" was shown to have contributed inaccurate information on at least one prior occasion. 
cited with approval the affidavit in Jones $v$. United States. ${ }^{34}$ The Jones affidavit listed one prior instance of accurate information, but left open the possibility that the informer had produced inaccurate information on other occasions. Rugendorf $v$. United States, ${ }^{35}$ decided the same term as Aguilar, also approved a superficial showing of the basis for the searching officer's belief in rehability.

In Rugendorf; Chicago FBI agents received information from several "reliable informers" which dovetailed to indicate that the defendant's brother was a fence for furs stolen in an Alabama robbery six months before. Another informer, who, it was alleged without supporting particulars, had "furnished reliable information in the past," indicated that he had seen furs of the type and amount stolen in the basement of the defendant's home. The agents made no personal observations of the defendant's conduct and he was not previously known to them as in Jones. The Court sustained a finding of probable cause. Quite possibly, there would have been a different result without the recitals of reliability, yet the Court insulated the recitals from attack. The Court found that the commissioner need not have required disclosure, smce there was a "substantial basis for crediting the hearsay."

Where, as in Aguilar, the warrant is based on the informer's information alone, a stronger showing on reliability should be required. Jones and Rugendorf can be interpreted, however, as permitting a less convincing showing where there is some corroboration of the informer's report, even though that corroboration is not strong enough independently to suggest the truth of the information. ${ }^{37}$ In both cases, similar reports from other informers were received, and in Jones, the defendant was already known to police as a narcotics user. Nevertheless, the reviewing magistrate should be given some conception of how rehable the particular informer is. Different corroborative contexts might then suggest, according to their varying strengths, what the probabilities are that the informer is informing reliably on the occasion in question. With little or no corroboration, a very convincing demonstration of reliability might be demanded; with somewhat stronger corroboration, a less elaborate showing of personal reliability might suffice.

34378 U.S. at 114-15.

35376 U.S. 528 (1964).

${ }^{36}$ Id. at 533. Petitioner also maintained that he was entitled to disclosure because "relevant and helpful" to his defense. Roviaro v. United States, 353 U.S. 53 (1957), discussed in note 3 supra. The Court held that the demand had not been sufficiently raised below, and refused to consider disclosure under Roviaro.

37 But see Perry v. United States, 336 F.2d 748 (D.C. Cir. 1964). Officers acting on a tip observed the defendant talking with known addicts and saw an "exchange of something." Testimony that the informer had given "about three" tips in the past three months which had "proven reliable" was considered inadequate under Aguilar. 
The "reliable information in the past" recital of Rugendorf seems too vague even under this standard, for it lacks any factual indication of how reliable the informer is. The inagistrate is, in effect, relying upon the factual determination of the arresting officer that the informer is sufficiently reliable, and not upon his own independent judicial determination. ${ }^{38}$ This does not square either. with the :Aguilar demand for "underlying circumstances" or with the requirement that the essential facts supporting the assertion of probable cause be made known to the reviewing magistrate. ${ }^{39}$ Where reliability is important, the facts supporting reliability are as essential as any others to a showing of probable icause.. With such facts, the magistrate can challenge the reasonableness cof the officer's belief in his informer's reliability. When the further possibility is considerẽd that an officer has not made a good faith assessment of the infornner's rehability, or may even know him to be unrehable, the dangers;in acceptance of vague averments of reliability become even more obvious. Judicial acceptance may tempt officers to make superficial averments of reliability without proper support; and some officers, while they may be above wholesale fabrication, may not be averse to some stretching of the truth on occasion. ${ }^{40}$

The procedural implications of judicial laxity are most serious for a defendant in the warrant cases. ${ }^{41}$. If courts uphold such recitals against motions to suppress for lack of probable cause, the defendant's only protection against bad faith or insufficiently supported recitals is the alternative of admitting probable cause on the face of the warrant and attacking the supporting averments of the 'affidavit as themselves untrue-a disputed procedure in the federal courts. ${ }^{42}$

38 See United States v. Elgisser, 334 F.2d 103, 110 (2́d Cir.) (dictum), cert. denied, 379 U.S. 881 (1964).

39 Giordenello v. United Stàtes; 357 U.S. 480, 486 (1958).

- 40 See, e.g., United States v. Elgisser, 334 F.2d 103 (2d Cir.), cert. denied, 379. U.S. 881 (1964) (FBI agent testified that informer was reliable, but admitted that he did not know who informer was); United States v. Péarce, $275^{\prime}$ F.2d 318 (7tls Cir. 1960) (no previous contacts with "reliable informer" by either affiant or agent 'who had received communication); Lerner v. United States, 151 A.2d 184 (D.C. Mun. Ct. App. 1959) (affidavit that information received in preceding month, whereas in fact received earlier in year).

41 There are also a number of non-warrant cases which, while relying heavily on reliability, contain only vague or unsupported recitals of reliability supplemented by nothing more than innocent corroboration. The cases, however, probably should not be taken as holding those recitals imnune from challenge. See notes 30-31 supra and acconpanying text. Where such recitals have been accepted, the failure of the defendant to challenge the recital has -sometinies been noted. E.g., United States v. Rivera, 321 F.2d 704 (2d Cir. 1963); Bourg v. United States, 286 F.2d 124 (5th Cir. 1960). Such cases imply that a demand for elaboration would have been upheld.

42 One line of cases holds that the magistrate need not investigate the truth of an affidavit, and if there is probable cause on the face of the affidavit, there can be no challenge to the veracity of its underlying averments. E.g., Kenny v. United States, 157 F.2d 442 
Even admitting the correctness of such an attack, the movant under Federal Rule of Criminal Procedure 41(e) probably must support his motion to suppress with something more than mere suspicion that the facts of the affidavit are untrue.: : $^{43}$ Because the facts determining the truth or falsity of averments that an informer existed or that he was reliable lie peculiarly. within the knowledge of the officer, the movant is unlikely to have any definite knowledge or evidence to support his motion to suppress. 44

A backdoor approach would be to cliallenge any averment about which the defendant did lave some contrary evidence. Though the proven falsity of one item might leave the probable cause showing intact, the affiant's veracity might be regarded as sufficiently impeached to allow a general inquiry into the truth of all of the affidavit's averments, including reliability.

Rugendorf $v$. United States ${ }^{45}$ suggests the potential success of such an approach. The defendant proved that a statement of one of the informers, to the effect that the defendant was a copartner and manager with his brother of a meat market, was untrue. Admitting, arguendo, the correctness of the attack, ${ }^{46}$ the Court nevertheless dismissed the erroneous statement as "peripheral" to the probable cause showing and as not touching the averments of the agent himself, therefore not impeaching the integrity of the affidavit. The implication left, however, was that if one of the averments of the agent himself had been proven false, the veracity of the rest of the affidavit, including the assertion of reliability, would have been open to general review.

But should the defendant's opportunity to challenge a recital of reliability depend on the chance that the affidavit contains a detectable falselood? The insufficiently supported or bad faith recital of reliability may be the only flaw im an otherwise unexceptionable affidavit. Because a motion to suppress is often the main line of defense in those cases

(D.C. Cir. 1946) ; United States v. Gianaris, 25 F.R.D. 194 (D.D.C. 1960); United States v. Doe, 19 F.R.D. 1 (E.D. Tenn. 1956). Another line of cases holds that the veracity of the averments, as well as their sufficiency to establish probable cause, may be challenged. E.g., King v. United States, 282 F.2d 398 (4th Cir. 1960); United States v. Pearce, 275 F.2d 318 (7th Cir. 1960); Townsend v. United States, 253 F.2d 461 (5th Cir. 1958). The Supreme Court has never been directly confronted with the issue. See Rugendorf v. United States, 376 U.S. 528 (1964), admitting, arguendo, the correctness of the procedure:

43 See United States v. Warrington, 17 F.R.D. 25 (N.D. Cal. 1955); cf. United States v. Weinberg, 108 F. Supp. 567 (D.D.C. 1952) (affidavit based on suspicion and innuendoes insufficient to merit hearing on motion to suppress alleged wiretap evidence).

44 In contrast, a defendant could say with authority whether or not allegations of a past criminal record or suspicious conduct were true.

45376 U.S. 528 (1964).

46 See generally cases cited note 42 supra. 
[Vol. 53: 840

where informers are relied upon, such a restricted procedure is inadequate. ${ }^{47}$

A preferable alternative would be more thorough compliance with Aguilar's demand for elaboration of the underlying circumstances for the officer's belief. Some factors relevant to the question of reliability and necessary to an adequate elaboration are: the length of time the officer has known and dealt with the informer, ${ }^{48}$ the number of tips received, ${ }^{40}$ the character of the information received, ${ }^{50}$ the general reputation of the informer, ${ }^{51}$ the manner in which the informer was paid for his information, ${ }^{52}$ and whether, in narcotics cases, the informer was himself an

47 The majority of reported cases involving suppression of evidence concern narcotics violations. Since mere possession of narcotics is sufficient evidence for conviction, 70 Stat. 570 (1956), 21 U.S.C. § 174 (1964), the burden is on the defendant to bring forth evidence justifying such possession. Roviaro v. United States, 353 U.S. 53, 63 (1957). The burden of bringing forth exculpatory evidence often makes a motion under Federal Rule of Criminal Procedure $41(e)$ the only fcasible mode of defense.

48 See, e.g., Draper v. United States, 358 U.S. 307 (1959) (six months); Jones v. United States, 271 F.2d 494 (D.C. Cir. 1959), cert. denied, 362 U.S. 944 (1960) (five years); Brandon v. United States, 270 F.2d 311 (D.C. Cir. 1959), cert. denied, 362 U.S. 943 (1960) (over a year).

49 There is no apparent minimum. One previous tip may be enough under proper circumstances. See Jones v. Umited States, 362 U.S. 257 (1960).

50 The word of an inforner whose information on previous occasions has led to arrest and seizure of narcotics, see, e.g., Rose'v. United States, 313 F.2d 666 (9th Cir. 1963), should probably be accorded more weight than that of one who has only furnished general information. But see Hawkins v. Umited States, 288 F.2d 537 (8th Cir.), cert. denied, 366 U.S. 975 (1961). "Some" of the statements of a previously unknown informer concerning narcotics activity in the Chicago area were verified. The court found that his reliability had been established. Comprehensive discussion and analysis of the legitimate grounds for behief in reliability have been so limited that it is difficult to say wbether such a showing is generally sufficient.

51 Some courts have balked at a concept of reliability that would include a general reputation for truthfulness, apart from a history of accurate tips on criminal activity. See, e.g., Schoeneman v. Umited States, 317 F.2d 173 (D.C. Cir. 1963); United States v. Sawyer, 213 F. Supp. 38 (E.D. Pa. 1963) (busmess executive previously employed by both the Justice and Treasury' departments). At least one case, however, has accepted a showing of reliability based on the arresting detective's statement that he "had had previous dealings" with the store owner-informer and "knew him to be a man of honesty and reliability." Rogers v. Umited States, 330 F.2d 535 (5th Cir. 1964). There seems no good reason for rejecting such a recital of general reliability when it is based on personal contact. Greater difficulties might confront the courts if they attempted to decide in the abstract wbat classes and types of persons are entitled to classification as "reliable." But see Naples v. United States, 307 F.2d 618 (D.C. Cir. 1962) (brother of defendant treated as rehable informer without discussion).

52 See, e.g., Perry v. United States, 336 F.2d 748 (D.C. Cir. 1964). Efficient police practice would seem to demand payment only upon verification of the informer's information. See Umited States v. Robinson, 325 F.2d 391 (2d Cir. 1963), where a successful arrest and seizure were made and the informer paid "at some later tine" by the Government. If the informer is paid only after his information has been confirmed, he is less likely to submit lying or inaccurate information.

Payment to informers out of specific funds and collected fines is authorized by statute. 
addict. ${ }^{53}$ Probably no set standard can be formulated for the extent of such a showing: The requisite particularity would probably come to depend on the amount and quality of the added corroboration present in each case, with the policy of the informer's privilege as a check against unduly extensive showings. With such an approach, at least, the danger of a warrant issuing on an officer's good faith misjudgment as to the informer's reliability is greatly diminished. Any tendency to slip into an easy recital of reliability is also reduced.

\section{III}

\section{DISCLOSURE AS THE ULTIMATE SAFEGUARD}

There is one remaining weakness in the safeguards against an illegal search and seizure so far elaborated. There is no sure check against the possibility that an officer might try to lie his way to a showing of probable cause. Testimony of the informer is the most effective safeguard against this danger. Cross-examination of the officer alone may expose good faith misjudgment or force elaboration of superficial averments; whether it provides sufficient protection against a witness predisposed toward lies and half-truths is more questionable. The defendant cannot draw on his own knowledge of the facts to impeach averments regarding receipt of the information, a history of rehiability, and the contents of the infornation. Even those showings where there is such ample corroboration that reliability and the informer's basis need not be inquired into ${ }^{54}$ are subject to this infirmity. In such cases, all that need be established in addition to the corroborating facts is mere receipt of infornation inplicating the defendant in criminal activity. If an officer has made a successful arrest and search based on what, upon later reflection, are recognized as insufficient grounds, it would be a simple matter to convert those insufficient grounds into sufficient corroboration merely by inventing an informer. Alleged receipt of information from an informer may be the crucial factor that validates an otherwise unlawful arrest. ${ }^{55}$

E.g., 38 Stat. 277 (1914), 21 U.S.C. § 183 (1964) (awarding informer share of fine in illegal narcotics export cases); 46 Stat. 850 (1930), 21 U.S.C. $\S 199$ (1964) (authorizing payment for information leading to seizure of contraband narcotics).

63 See, e.g., Perry v. United States, 336 F.2d 748 (D.C. Cir. 1964). With an addictinformer in need of quick money to support his habit, physical need plus payment merely on receipt of information obviously may combine to engender false information. Some pohice departments have been known to compensate the addict-informer directly with narcotics. See Jones v. United States, 266 F.2d 924, 928 (D.C. Cir.) (granting leave to appeal in forma pauperis, statement by Bazelon, J.), appeal on merits, 271 F.2d 494 (D.C. Cir. 1959), cert. denied, 362 U.S. 944 (1960); Harney \& Cross, THE Insorarer IN LAW ENFORCEMTENT 54 (1960).

54 Cases cited notes 14-17 supra and accompanying text.

65 See United States v. Bianco, 189 F.2d 716 (3d Cir. 1951) (informer's infornation, 


\section{A. The Warrant Cases}

In the warrant cases, the decision to require disclosure has been made discretionary with the commissioner, provided there exists in the affidavit a substantial basis for crediting the hearsay. ${ }^{56}$ Confirming the truth of the affidavit is left to the commissioner, the apparent view being that he can perform this function adequately without mandatory disclosure. This though the commissioner's often perfunctory ex parte examination $^{57}$ is not meant to determine the truth of averments ${ }^{58}$ but to examine their legal sufficiency to establish probable cause. The unstated rationale behind the holdings seems to be that the extensiveness of the required showing will challenge both the inventiveness and conscience of all but a few of those affiants who are so disposed. In addition, few officers are likely to hazard false averments when there is no assurance that the intended search will prove successful. ${ }^{59}$ On balance, the few illegal searches that would be prevented by making disclosure mandatory for issuance of a warrant are probably not worth the price to be paid in sources of information lost.

\section{B. The Non-Warrant Cases}

Regarding the necessity for disclosure where no warrant has first issued, the case law is conflicting. The Supreme Court has never passed directly on the issue $e^{00}$ and the lower courts have arrived at a variety of

considered in relation to other elements, constituted an important "corroborative and additive" factor in establishing probable cause).

56 Rugendorf v. United States, 376 U.S. 528 (1964); Jones v. United States, 362 U.S. 257 (1960).

57 See Evans v. Umited States, 242 F.2d 534 (6th Cir.), cert. denied, 353 U.S. 976 (1957). The affiant, a private citizen, averred that the defendant was possessed of moonsbine whisky. He was asked by the commissioner if he had correctly identified himself, whether he understood the contents of the affidavit, and whether it was true. Receiving an affirmative reply, the commissioner issued the search warrant. Probable cause was sustained.

58 The commissioner may take the affidavit as it is presented and need not investigate whether its statements are true. United States v. Doe, 19 F.R.D. 1 (E.D. Tenn. 1956); United States v. Brunett, 53 F.2d 219 (W.D. Mo. 1931).

69 In comparison, the non-warrant situation probably involves a greater danger of prevarication, since justification for the arrest or search comes only after a successful search has been consummated.

60 In Husty v. United States, 282 U.S. 694 (1931), the Court declined to consider the issue since it had not been raised on appeal in the court of appeals. In Scher v. United States, 305 U.S. 251 (1938), the Court found a decision unnecessary since the Governinent had established probable cause independent of any reliance on the informer's information. In Draper v. United States, 358 U.S. 307 (1959), disclosure was obtained in the district court, and the Court had no occasion to discuss the necessity of such a procedure. A dictum in Roviaro v. United States, 353 U.S. 53, 61 (1957), referred with apparent approval to the probable cause cases which had previously required disclosure of the informer "unless there was safficient evidence apart from his confidential commumication," but since Roviaro was concerned with a participant informer, there was no elaboration of a definite Supreme Court position on probable cause cases. 
answers. A few courts have held that disclosure may be required only in cases where the informer was an actual participant in or witness to the crime, his testimony thus being useful on the issue of guilt or innocence. ${ }^{b 1}$ Other courts have conceived of the informer's usefulness as limited to establishing his own reliability. ${ }^{62}$ They have then dismissed the request for disclosure on the basis that the informer would be a poor witness on this issue. ${ }^{63}$ In conflicting cases ${ }^{64}$ disclosure has been regarded as essential where reliability must be established as part of the probable cause showing. As a corollary, it has been held that disclosure need not be required where the information is sufficiently corroborated, since rehability is no longer relevant. ${ }^{65}$ Still other courts have held disclosure to be essential regardless of the degree of corroboration, ${ }^{68}$ evidencing their view that disclosure serves as a cross-check on the officer's veracity.

This last view regarding the function of disclosure is probably the soundest. It is set forth in United States v. Robinson, ${ }^{67}$ a recent Second Circuit case. The court there remanded for disclosure, stating that where an mformer is relied upon for probable cause, the defendant may properly seek disclosure in order to learn by what means the informer had gaimed his knowledge, why the officer considered the informer reliable, and whether information was in fact received by the officer. The de-

B1 E.g., United States v. Rugendorf, 316 F.2d 589 (7th Cir. 1963), aff'd on other grounds, 376 U.S. 528 (1964); United States v. Whiting, 311 F.2d 191 (4th Cir. 1962), cert. denied, 372 U.S. 935 (1963); United States v. Li Fat Tong, 152 F.2d 650 (2d Cir. 1945).

02 E.g., Jones v. United States, 326 F.2d 124 (9th Cir. 1963), cert. denied, 377 U.S. 956 (1964); United States v. One 1957 Ford Ranchero Pickup Truck, 265 F.2d 21 (10th Cir. 1959).

83 The court in Jones v. United States, supra note 62 , at 129 , concluded: "[T] his reliability is in the mind of ... [the police officer], not ... [the informer]. Cross-examination of ... [the informer] to prove his own reliability would not be legally fruitful." A dissenting judge noted that the informer's story as to prior dealings with the officer might contradict the officer's story, thus destroying the officer's credibility in the eyes of the trier of fact. Id. at 130 .

64 E.g., United States v. Elgisser, 334 F.2d 103 (2d Cir.), cert. denied, 379 U.S. 881 (1964); Cochran v. United States, 291 F.2d 633 (8th Cir. 1961); United States v. Bhich, 45 F.2d 627 (D. Wyo. 1930); United States v. Keown, 19 F. Supp. 639 (W.D. Ky. 1937).

65 E.g., United States v. Elgisser, supra note 64; Buford v. United States, 308 F.2d 804 (5th Cir. 1962) (per curiam) ("sufficient corroborating evidence ... to protect the identity of the informer").

${ }^{66}$ E.g., United States v. Robinson, 325 F.2d 391 (2d Cir. 1963); United States ex rel. Coffey v. Fay, 234 F. Supp. 543 (S.D.N.Y. 1964); accord, United States v. Santiago, 327 F.2d 573 (2d Cir. 1964); United States v. Rosario, 327 F.2d 561 (2d Cir. 1964); see Wilson v. United States, 59 F.2d 390 (3d Cir. 1932). But see United States v. Elgisser, 334 F.2d 103 (2d Cir.), cert. denied, 379 U.S. 881 (1964), a later Second Circuit case which suggests that sufficient corroboration can remove the need for disclosure. Lumbard, J., author of the Robinson, Rosario, and Santiago opinions, concurred separately, 334 F.2d at 111, maintaining that probable cause apart fron the informer's information had been established.

67325 F.2d 391 (2d Cir. 1963). 
fendant was "not required to take ... [the agent's] word for this." Even had there been an elaboration of "underlying circumstances" in Robinson, ${ }^{69}$ disclosure would probably have been required, since the defendant, if he was not required to take the officer's word as to receipt of the information, certainly would not be required to take the officer's word on the existence of past instances of accurate information. Robinson apparently requires, then, that whenever an informer is relied upon for probable cause in a non-warrant case, the informer must be disclosed. ${ }^{70}$ Corroboration and elaboration of underlying circumstances are irrelevant; the actual receipt of information must always be verified.

Robinson places emphasis on what seems the chief value of disclosure: testing the officer's veracity. Because facts supporting both the informer's accusation and his asserted reliability can be supplied by the Aguilar requirement of elaboration, ${ }^{71}$ cases which regard proof of rehabihity as the purpose of disclosure seem beside the mark, although disclosure would concededly allow a less inhibited inquiry into the informer's history and the basis for his allegations.

Conceding that the utility of disclosure lies in its cross-check on veracity, the more important question which remains is whether Robinson is right in making it mandatory. Because of the judicial bias in favor of warrants, there would be no inconsistency in applying the stricter mandatory standard only to non-warrant cases. ${ }^{72}$ The question must therefore be resolved on a consideration of several substantive issues: the comparative likelihood of fabrication by the arresting officer in the warrant and non-warrant contexts, the practical effectiveness of disclosure, and the possible detriment caused law enforcement efforts by a mandatory disclosure requirement in non-warrant informer cases.

It seems fair to assume that the possibility of lies or half-truths

68 Id. at 393. Draper v. United States, 358 U.S. 307 (1959), was treated as in harmony with the court's decision. At the pretrial hearing in Draper, the Government had acceded without protest to the defendant's demand for disclosure of the informer's identity, since the inforner bad died four days after the arrest. Similarly, the court found nothing to the contrary in Jones v. United States, 362 U.S. 257 (1960), noting that the commissioner could have requested disclosure if he had so desired.

69 The defendant immediately requested disclosure at the pretrial hearing without first making general inquiries into the informer's reliability or the basis for his information.

70 A later case, United States ex rel. Coffey v. Fay, 234 F. Supp. 543 (S.D.N.Y. 1964), has so interpreted Robinson.

71 For non-warrant cases using such a procedure, see Perry v. United States, 336 F.2d 748 (D.C. Cir. 1964); Jackson v. United States, 336 F.2d 579 (D.C. Cir. 1964) (per curian).

72 Where a warrant has first been secured, "courts will accept evidence of a less "judicially competent or persuasive character than would have justified an officer in acting on his own without a warrant' ...." Aguilar v. Texas, 378 U.S. 108, 111 (1964). Given this established judicial preference, disclosure might justifiably be made mandatory in nonwarrant cases, substituting for "less judicially competent" hearsay evidence the direct testimony and cross-examination of the informer himself. 
is enhanced in the non-warrant cases simply because the search has already been made and the contraband seized before the existence of probable cause is submitted to judicial scrutiny. The pressures on an officer seein greater here to stretch the truth or to indulge in what he nay be able to rationalize as a harmless lie, given his firsthand knowledge of the defendant's guilt. Further, it may be embarrassing for an officer to candidly admit that his assessment of probable cause was wrong, particularly when his error means the collapse of the case against the defendant.

Discussion of the increased possibility of fabrication is not too helpful in weighing substantive considerations, however, without some idea of how much increase is involved. A propensity for perjured testimony is not hightly to be ascribed to any segment of the population, particularly police officers. More is involved, from the officer's standpoint, than employing a questionable or even illegal police practice which may be fairly widespread and sanctioned by pohce usage. Although a particular officer inight customarily use such methods, that same officer in most cases would balk at lying under oath, for such conduct lacks sanction in police usage or elsewhere. ${ }^{73}$ Suffice it to say that any increase in the likelihood of false testimony is probably not so great as to clearly eliminate a need for examination of competing considerations which argue against the wisdom of mandatory disclosure.

The practical effectiveness of disclosure is one such consideration. Assuming for the moment that the informer's testimony would be an effective means of testing veracity, it should be recognized that, as a practical matter, disclosure of the informer's identity does not inevitably lead to his appearance and testimony in court. It has been held that the government must make reasonable efforts to locate the informer once disclosure has been ordered, ${ }^{74}$ or at least provide the defendant with his name and address. ${ }^{75}$ However, there are numerous examples in the case law where disclosure has been ordered, thus depriving police of an informer's future services and discouraging potential sources of information, yet the informer has not subsequently testified. ${ }^{76}$ Many informers are probably transient individuals, for whom the police have no reliable

73 For evidence that officers, even highly regarded FBI agents, do, on occasion, transcend the realm of fact and enter that of imagination, see note 40 supra.

74 E.g., White v. United States, 330 F.2d 811 (8th Cir.), cert. denied, 379 U.S. 855 (1964); United States v. Clarke, 220 F. Supp. 905 (E.D. Pa. 1963).

75 United States v. Goss, 237 F. Supp. 26 (S.D.N.Y. 1965).

${ }^{76}$ E.g., Costello v. United States, 324 F.2d 260 (9th Cir. 1963), cert. denied, 376 U.S. 930 (1964), affirming after vacation and remand in 298 F.2d 99 (9th Cir. 1962); Butler v. United States, 273 F.2d 436 (9th Cir. 1959) (informer disclosed, but "neither side despite diligent effort could locate him"); Brandon v. United States, 270 F.2d 311 (D.C. Cir. 1959), cert. denied, 362 U.S. 943 (1960) (police did not have informer's address). 
address. ${ }^{77}$ Others may be known to the police only by nicknames or aliases. ${ }^{78}$ Also, some courts have been reluctant to require that the government anticipate a call for disclosure by obtaining in advance specific information concerning the name, address, and general whereabouts of the informer. ${ }^{79}$ Even if such informative efforts are to be required of police, many informers can be expected to evade police efforts to contact them when they know that their testimony is needed, or to refuse to appear even after being contacted by police. ${ }^{80}$ The probability that disclosure will or will not actually result in testimony seems a valid practical consideration weighting the scales in favor of sustaining the informer's privilege.

A similar consideration concerns the value of the informer's testimony, assuming that he actually appears. Denial that lie gave sucl information as alleged may be only a device of the informer to insure his own safety. Testimony corroborating an officer's testimony may not be reliable either. If it is assumed that the officer may be lying under oath, the assumption might be carried further: the same officer miglit be procuring the favorable testimony of the informer by offering him certain inducements such as money or favorable treatinent. Such eventualities may of course be checked somewhat by skillful cross-examination, but the possibility of the informer's own doubtful veracity under oath is still a factor in considering the effectiveness of disclosure in achieving its end.

Finally, mandatory disclosure would burden law enforcement efforts in some instances. It may be argued that if an officer felt that information received from an informer provided grounds for arrest and lie also felt that the informer was reliable, he could obtain an arrest warrant ${ }^{81}$ as a means of avoiding mandatory disclosure at the hearing on the motion to suppress. However, no such alternative would be offered officers in situations where there is no time to seek a warrant. ${ }^{82}$ Here, the officer

77 See Brandon v. United States, supra note 76.

78 See United States v. McKay, 283 F.2d 399 (7th Cir. 1960), cert. denied, 365 U.S. 813 (1961) (three informers known to police only as "Rabbit," "Lightning," and "Ham Man").

79 See United States v. Pruitt, 331 F.2d 232 (7th Cir.), cert. denied, 379 U.S. 884 (1964) (unreasonable to require that government "speculate on the possible needs of the defense"). Such a sympathetic judicial approach, lowever, might encourage officers to deal with tbeir informers on an anonymous, or nearly anonymous basis, making disclosure either impossible or of little practical value. See HarNeY \& Cross, The INFORMER IN LAW ENFORCEArENT 64 (1960).

80 See White v. United States, 330 F.2d 811 (8th Cir.), cert. denied, 379 U.S. 855 (1964) (informer had been spotted on street by agent three weeks prior to trial and told to report to the United States attorney).

81 FED. R. CRnM. P. 3, 4.

82 E.g., Perry v. United States, 336 F.2d 748 (D.C. Cir. 1964), where officers received 
would be confronted with the difficult choice of going ahead with the arrest, knowing that the informer would have to be disclosed, or letting the offender go free in order to preserve his source of information. The threatened prevarication of a few would subject many honest officers to this difficult election.

A compromise approach, more flexible than such a Procrustean rule of disclosure, yet short of the discretion allowed the commissioner, might be to make disclosure mandatory only where there had been time to secure a warrant-a rule analogous to that which allows a search to be conducted without a warrant if prior procurement of a search warrant was impracticable. ${ }^{83}$ The honest officer could then protect against disclosure where he had sufficient time, and yet not be faced with mandatory disclosure if obtaining a warrant proved impracticable. For the residue of cases where there was not time to secure a warrant, the judge, using guidelines such as the amount and type of corroboration, the officer's performance and demeanor under cross-examination, previous experience with the officer as a witness, and an awareness of the increased possibility of perjured testimony in the non-warrant situation, could tailor his decision on disclosure to the individual case.

The impracticability of securing a warrant may be criticized, however, as an inadequate basis for the mandatory-discretionary distinction. It does not segregate cases according to the comparative likelihood of perjured testimony, but upon considerations of police convemience. Thus, the likelihood that an officer will invent an informer or fabricate a history of reliability is at least as great where there has been no time to secure a warrant as where there has been sufficient time. It may even be somewhat greater, since the need for immediate action may inhibit the more thorough investigation which may be necessary to develop a solid probable cause basis for the arrest. The defendant in a case where it has been impracticable for police to secure a warrant derives no aid or comfort from the fact that the danger of perjured testimony which he confronts is curtailed in most cases by mandatory disclosure.

The weakness of such an argument is its appraisal of the validity of the suggested rule from the defendant's standpoint alone and its consequent neglect of competing factors which, on a consideration of the whole picture, may justify the criterion selected. Such a one-sided approach does, however, draw support from certain language in Roviaro v.

word by phone that the accused was at that moment selling narcotics on a certain streetcorner.

83 See Carroll v. Umited States, 267 U.S. 132 (1925) (moving vehicle); Husty v. United States, 282 U.S. 694 (1931) (parked auto which could have been moved at any time). The one other exception to the requirement of a search warrant allows a search incident to a valid arrest. United States v. Rabinowitz, 339 U.S. 56 (1950). 
United States, ${ }^{84}$ which dealt with a participant informer, ${ }^{85}$ but put forth a disclosure formula broad enough for general application. The Court said: "Where the disclosure of an informer's identity ... . is relevant and helpful to the defense of an accused, or is essential to a fair determination of a cause, the [informer's] privilege must give way." isolation, such wording does carry the implication that the defendant's needs are the only ones to be looked to. If this is a true interpretation, there is no justification for regarding disclosure as "essential to a fair disposition of [the] cause" where there has been time to get a warrant and regarding it as not essential where obtaining a warrant has proved impracticable. Disclosure is equally "essential," from the defendant's standpoint, in both cases. The probable cause cases which have so interpreted Roviaro, however, seem to liave overlooked later language in the opinion which imports a balancing approach: ${ }^{87}$

$[N]$ o fixed rule with respect to disclosure is justifiable. The problem is one that calls for balancing the public interest in protecting the flow of information against the individual's right to prepare his defense. Whether a proper balance renders non-disclosure erroneous must depend on the particular circumstances of each case. ${ }^{88}$

Since the public interest in protecting the informer may be adequately served by securing a warrant where there is time, the balance may be struck in favor of mandatory disclosure in sucli cases. Where, lowever, the police are not provided with such an opportunity, the balance has arguably shifted enough to inake discretionary disclosure a valid compromise approach.

Admittedly, the defendant's protection against perjured testimony is less certain where disclosure depends upon a judge's subjective appraisal of the witness's veracity. However, the danger is recognized, and a judicial check, albeit one of possibly imperfect application, is interposed. There may be instances where perjured testimony does slip through. The consequence, however, would not be the conviction of an innocent man, but the admission of evidence which is itself perfectly unimpeachable in cliaracter.' Probable cause, not guilt or innocence, is at stake. The comparative seriousness of the possible consequences flowing from non-disclosure in different situations seems a valid factor in the balancing process suggested by Roviaro.

All considered, such a hybrid disclosure rule is perhaps the best

84353 U.S. 53 (1957).

85 See note 3 supra.

86353 U.S. at 60-61.

87 See, e.g., United States v. Robinson, 325 F.2d 391 (2d Cir. 1963); United States ex rel. Coffey v. Fay, 234 F. Supp. 543, 550 (S.D.N.Y. 1964).

88353 U.S. at 62 . 
alternative. It recognizes and deals with the increased possibility of overly imaginative or untruthful testimony where no warrant lias first been secured by making disclosure mandatory in inost cases. However, it tempers the force of the argument that loss of the informer through disclosure is not sufficiently compensated by the practical effectiveness of the device by allowing opportunity to avoid mandatory disclosure, and by making disclosure discretionary where there is no such opportunity.

\section{CONCLUSION}

Where the prosecution is able to establish probable cause independent of the informer's communication, using it only as a starting point for investigation, invocation of the informer's privilege works no harm. A different problem arises when the government uses such information as a necessary part of its case.

In cases where sufficient corroboration is lacking, some inquiry into the informer's reliability and the basis for his information has been deemed essential. Any sucl inquiry, of course, depending on how particularized and extensive future cases may desire to make it, will tend to reveal the informer's identity and so to that extent quahify the informer's privilege. Such inquiry is necessary, however, in order to maintain the determination of probable cause as the function of the reviewing magistrate and not that of the police officer or his informer.

The warrant cases have chosen to halt infringement of the government's privilege at this point, and have not taken the final stepmandatory disclosure of the informer's identity. The Supreme Court has apparently regarded the problem of false testimony as not of sufficient moment where a warrant has first been issued, and has left the most effective check on an officer's veracity-disclosure-to the commissioner's discretion.

The position of the Supreme Court and the other federal courts is unclear in cases where no warrant has been obtained. Arguably, the defendant would be sufficiently protected by the standards deemed adequate for the commissioner. However, it appears that a compromise rule of disclosure, part mandatory, part discretionary, may be a more satisfactory procedure for the non-warrant case. Judicial preference for warrants renders the stricter rule legitimate, and the increased danger of abuse makes it desirable. 